$\theta$

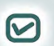

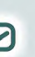

\title{
New records of Megalastrum in the northeastern Atlantic Forest
}

\author{
Rafael de Paiva Farias ${ }^{1 *}$, Augusto César Pessôa Santiago ${ }^{2}$, Anna Flora de Novaes Pereira ${ }^{3}$, \\ Ivo Abraão Araújo da Silva ${ }^{4}$ and Iva Carneiro Leão Barros ${ }^{1}$
}

1 Federal University of Pernambuco, Center for Biological Sciences, Department of Botany. CEP 50670-901. Recife, PE, Brazil

2 Federal University of Pernambuco, Academic Center of Vitória, Center for Biology. CEP 55608-903. Vitória de Santo Antão, PE, Brazil

3 Federal University of Vale do São Francisco, College of Natural Nature Sciences. CEP 64770-000. São Raimundo Nonato, PI, Brazil

4 Federal Rural University of Rio de Janeiro, Institute of Biology. CEP 23897-000. Seropédica, RJ, Brazil

Corresponding author. Email: rafaelpfarias@hotmail.com

\begin{abstract}
Megalastrum indusiatum R. C. Moran et al. and Megalastrum umbrinum (C. Chr.) A. R. Sm. \& R. C. Moran are reported for the first time in the Northeastern Atlantic Forest, extending the distribution of species in the Brazilian Atlantic Forest in about 680 and $1080 \mathrm{~km}$ to the north, respectively. Information on taxonomy and species distribution are provided.
\end{abstract}

Key words: Atlantic Forest, Brazil, Dryopteridaceae, ferns, Megalastrum

Megalastrum Holttum has about 90 species, mainly Neotropical, three of which occur in Africa-Madagascar region and six on islands of the Atlantic, Pacific, and Indian oceans (Moran and Prado 2010; Sundue et al. 2010; Rouhan and Moran 2011). The genus comprises terrestrial plants (rarely saxicolous), medium to large-sized, rhizomes erect to decumbent, 1-4 pinnate-pinnatifid (Moran and Prado 2010; Moran et al. 2014). It has important features for its distinction in the cutting blade, nervation, and axis indumentum in the adaxial part (Moran et al. 2009a, 2009b). The basal basiscopic pinnules gradually become decurrent and broadly adnate to the pinna rachis and it is supplied by a vein arising from the costa instead of the costula (Moran et al. 2009a, 2009b). Moran et al. (2009a) pointed out that the veins in most Megalastrum species end in hydathodes, before the lamina margins. Hairs in axes are coarse, whitish, multiseptate, with pointed tips, and antrorsely strigose or spreading (Smith and Moran 1987).

Megalastrum is a member of a clade informally recognized as the "lastreopsid ferns", which also includes Lastreopsis, Parapolystichum and Rumohra (Labiak et al. 2014). In Brazil there are 18 recorded species, 13 of which are endemic. All the species occur in Atlantic Forest areas and are absent from Amazonia (Moran et al. 2009a). The species are mainly distributed along the eastern coast of the southeast and southern regions of Brazil, and the complex of Serra do Mar stands out, a location considered as a center of endemism and diversity for the genus (Moran et al. 2009a). Megalastrum stands out in the country as the genus with the highest percentage of endemic species (72.2\%) (Prado and Hirai 2014). In the Atlantic Forest region, north of São Francisco river or the Northeastern Atlantic Forest, the occurrence of only one species was previously registered, Megalastrum eugenii (Brade) A. R. Sm. \& R. C. Moran.

By means of recent inventories of the fern flora in Northeastern Atlantic Forest remnants, namely the Murici Ecological Station - ESEC Murici (municipalities of Murici and Messias, Alagoas; $09^{\circ} 11^{\prime} 05.0^{\prime \prime} \mathrm{N}$, $035^{\circ} 45^{\prime} 20.0^{\prime \prime} \mathrm{W}$; 100-650 $\mathrm{m}$ above sea level) and the Natural Heritage Private Reserve - RPPN Pedra D’Antas (municipality of Lagoa dos Gatos, Pernambuco; $08^{\circ} 39^{\prime} 30.0^{\prime \prime} \mathrm{N}, 035^{\circ} 54^{\prime} 00.0^{\prime \prime} \mathrm{W}$; 400-750 m above sea level), two new records of the genus were obtained for the region, Megalastrum indusiatum R. C. Moran et al. and Megalastrum umbrinum (C. Chr.) A. R. Sm. \& R. C. Moran, respectively.

Megalastrum indusiatum R. C. Moran, J. Prado \& Labiak, Amer. Fern J. 99: 21. 2009.

DESCRIPTION AND ILLUSTRATION: Moran et al. (2009a). SPECIMEN EXAMINED: Alagoas, Murici/Messias, ESEC Murici, A.F.N. Pereira et al. 1400, date: 25 May 2010 (UFP 75.733).

DistRibution: Endemic to Brazil (Alagoas and Bahia) (Figure 1).

Comments: According to Moran et al. (2009a), Megalastrum indusiatum is characterized by 4-pinnatepinnatifid laminae at base, 2-pinnate-pinnatisect medially; non-glandular axes abaxially; and presence of indusia. Only two other species of the genus in Brazil are indusiate: M. adenopteris (C. Chr.) A. R. Sm. \& R. C. Moran and M. crenulans (Jacq.) A. R. Sm. However, M. 


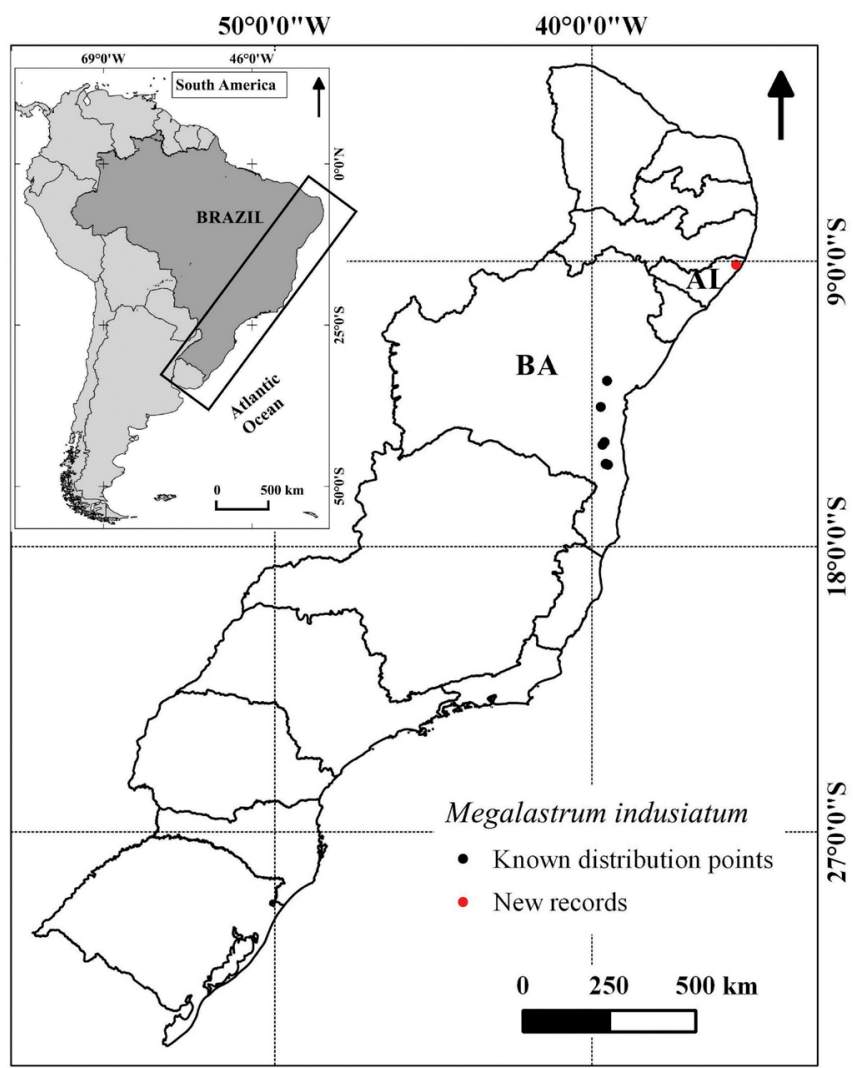

Figure 1. Distribution of Megalastrum indusiatum in Brazil (based on records shown by speciesLink Project; CRIA 2014). The red circles represents the new record (Murici/Messias-Alagoas).

indusiatum may be distinguished by persistent indusia (small sized) and lamina tissue between the veins adaxially glabrous (vs. indusia minute and fugacious; and laminae adaxially densely and evenly pubescent between veins in $M$. adenopteris). Also distinctive are the non-bullate scales on the pinna rachises abaxially (vs. indusia conspicuous, scales bullate on the pinna rachises abaxially; and lamina tissue between the veins adaxially glandular in M. crenulans) (Moran et al. 2009a; Prado and Hirai 2010).

HABITAT: Ravines and Forest Interior (small population) in moist and shady sites.

Megalastrum umbrinum (C. Chr.) A. R. Sm. \& R. C. Moran, Amer. Fern J. 77 (4): 129. 1987.

DESCRIPTION AND ILLUSTRATION: Moran et al. (2009a).

Specimen examined: Pernambuco, Lagoa dos Gatos, RPPN Pedra D’Antas, R.P. Farias et al. (15), date: 19 Oct 2012 (UFP 75.754).

Distribution: Paraguay and Brazil (Pernambuco, Bahia, Minas Gerais, Rio de Janeiro, São Paulo, Paraná, and Santa Catarina) (Figure 2).

Comments: Megalastrum umbrinum is characterized by 3-pinnate-pinatisect laminae at base, 2-pinnatepinnatisect medially; abaxial surfaces of axes densely puberulent with short glandular hairs, and acicular (nonglandular) hairs of various sizes (Moran et al. 2009a).

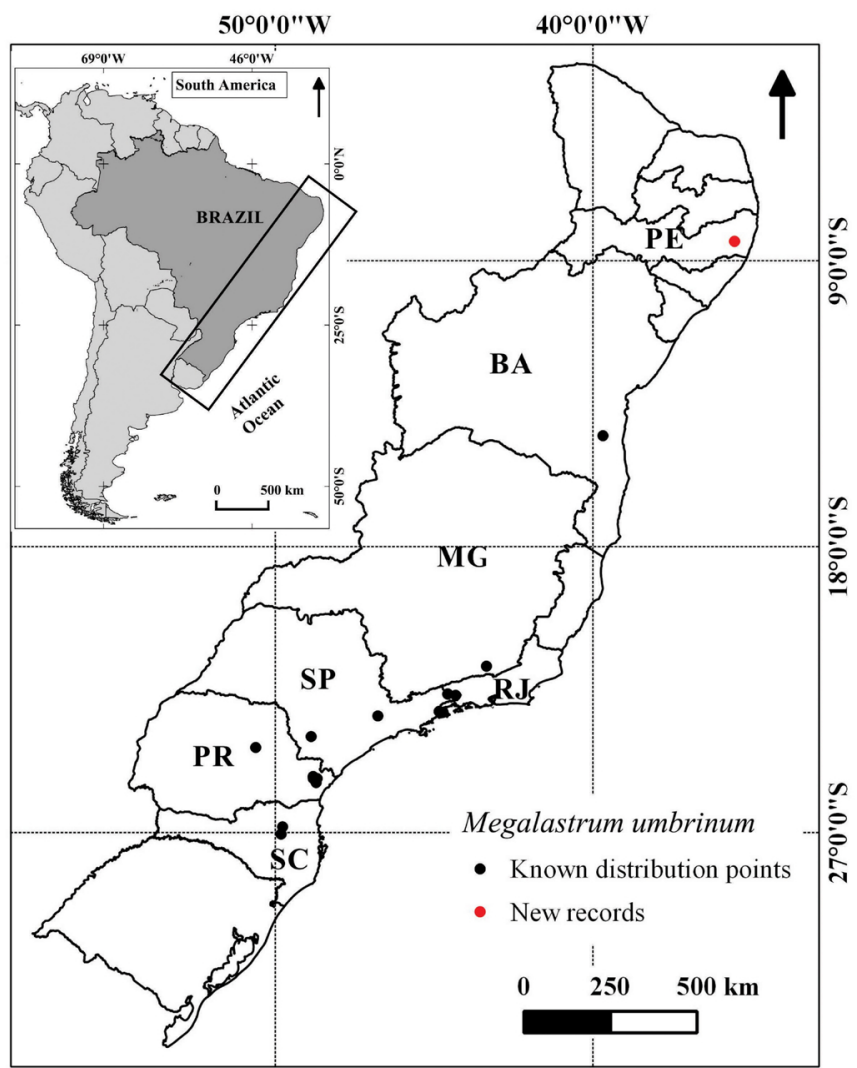

Figure 2. Distribution of Megalastrum umbrinum in Brazil (based on records shown by speciesLink Project; CRIA 2014). The red circles represents the new record (Lagoa dos Gatos-Pernambuco).

This species resembles $M$. adenopteris (C. Chr.) A. R. Sm. \& R. C. Moran, but it differs by laminae adaxially glabrous between veins or sparsely pubescent with a few hairs near the margins; rachis scales spreading, conspicuous, and absence of indusia ( $v s$. laminae adaxially dense and evenly pubescent between veins; rachis scales appessed, inconspicuous and minute fugacious indusia in $M$. adenopteris) (Moran et al. 2009a). In addition, distinctively, $M$. adenopteris have 4-pinnate-pinatisect laminae at base, 3-pinnate-pinnatifid medially (Moran et al. 2009a).

HABITAT: Forest Interior (small population).

In short, the distribution of $M$. indusiatum and $M$. umbrinum in the Brazilian Atlantic Forest, which was delimited up to southern Bahia (or the occurrence was restricted to this region, in the case of $M$. indusiatum), is extended here in about 680 and $1,080 \mathrm{~km}$ to the north, respectively (Figures 1 and 2). The interrupt pattern of distribution observed in occurrence of the new records has been shown to other ferns species, for example Pecluma recurvata (Kaulf.) M.G. Price (Santiago et al. 2014), Pteris schwackeana Christ (Prado, 2015), M. eugenii and Cyathea praecincta (Kunze) Domin (Matos et al. 2010). Usually, these species are widely distributed in Forest Atlantic areas from south and/or southeast to the south of the Bahia, with disjunct populations in the Northeastern Atlantic Forest. However, some forests 
remaining that occur in this interrupt area of distribution (Sergipe and/or Alagoas states) are undersampled in relation to ferns flora. Thus, only through the increase in sampling efforts on these areas will be possible to confirm this pattern of disjunct distribution. The species include new records for the Northeastern Atlantic Forest, demonstrating the importance of carrying out further inventories of ferns within this biogeographical unit. Finally, we highlight the need to keep the conservation efforts regarding both of these protected areas of the Northeastern Atlantic Forest, as well as the need to add new records for them, since these areas are rich in flora, there are 82 fern species in RPPN D'Antas (unpublished data) and 107 species in ESEC Murici (Pereira et al. 2013)

\section{ACKNOWLEDGEMENTS}

The authors thank to Dr. Paulo Labiak, for his help with species identification, Msc. Renê Macêdo, for his help in the preparation of maps, as well as the curator of Herbarium UFP, Marlene de Alencar Barbosa. We also thank to Dr. Robbin C. Moran for reviewing the manuscript, adding valuable comments and corrections.

\section{LITERATURE CITED}

CRIA (Centro de Referência e Informação Ambiental). 2014. Specieslink - simple search. Accessed at http://www.splink.org.br/index, 21 September 2014.

Labiak, P.H., M. Sundue., G. Rouhan., J.G. Hanks., J.T. Mickel and R.C. Moran. 2014. Phylogeny and historical biogeography of the lastreopsid ferns (Dryopteridaceae). American Journal of Botany 101(7): 1207-1228. doi: 10.3732/ajb.1400071

Matos, F.B., A.M. Amorim and P.H. Labiak. 2010. The ferns and lycophytes of a montane tropical forest in southern Bahia, Brazil. Journal of the Botanical Research Institute of Texas 4(1): 333-346.

Moran, R.C. and J. Prado. 2010. Megalastrum (Dryopteridaceae) in Central America. Kew Bulletin 65(2): 137-188. doi: 10.1007/ s12225-010-9214-3

Moran, R.C., J. Prado and P.H. Labiak. 2009a. Megalastrum (Dryopteridaceae) in Brazil, Paraguay and Uruguay. American Fern Journal 99(1): 1-44. doi: 10.1640/0002-8444-99.1.1

Moran, R.C., J. Prado and P.H. Labiak. 2009b. Megalastrum
(Dryopteridaceae) in the West Indies. Brittonia 61(3): 273-292. doi: 10.1007/s12228-009-9081-0

Moran, R.C., J. Prado and M.A. Sundue. 2014. Megalastrum (Dryopteridaceae) in Andean South America, Part I. American Fern Journal 104(3): 109-178. doi: 10.1640/0002-8444-104.3.109

Pereira, A.F.N., I.A.A. Silva., A.C.P. Santiago and I.C.L. Barros. 2013 Richness, geographic distribution and ecological aspects of the fern community within the Murici Ecological Station in the state of Alagoas, Brazil. Acta Botanica Brasilica 27(4): 788-8oo. (doi: 10.1590/So102-33062013000400019).

Prado, J. and R.Y. Hirai. 2010. Criptógamos do Parque Estadual das Fontes do Ipiranga, São Paulo, SP. Pteridophyta: 21. Tectariaceae. Hoehnea 37(2):367-376. doi: 10.1590/S2236-89062010000200009 Prado, J. and R.Y. Hirai. 2014. Biogeography of the Brazilian Atlantic Forest: evidence from phylogenetic data sets and perspectives for fern and lycophyte studies. Fern Gazette 19(7): 241-257. http://ebps.org.uk/publications/the-fern-gazette/fern-gazettevolume-19-part-7/

Prado, J. 2015. Pteridaceae in Lista de Espécies da Flora do Brasil. Jardim Botânico do Rio de Janeiro. Accessed at http://www. floradobrasil.jbrj.gov.br/jabot/floradobrasil/FB92003, January 2015

Rouhan, G. and R.C. Moran. 2011. Revision of Paleotropical Megalastrum (Dryopteridaceae). Annals of the Missouri Botanical Garden 98(1): 90-100. doi: 10.3417/2008129

Santiago, A.C.P., S.R.S. Xavier., M.R. Pietrobom and I.C.L. Barros. 2013 Pecluma recurvata (Kaulf.) M.G. Price (Polypodiopsida: Polypodiaceae): Distribution extension in Atlantic Forest, Brazil. Check List 9(3): 670-671. http://checklist.org.br/getpdf?NGD255-12

Smith, A.R. and R.C. Moran. 1987. New combinations in Megalastrum (Dryopteridaceae). American Fern Journal 77(4): 124-130. doi: $10.2307 / 1547480$

Sundue, M.G., G. Rouhan and R.C. Moran. 2010. Megalastrum (Dryopteridaceae) of the Circumaustral region: Chile, Argentina, and Southern Islands of the Atlantic, Pacific, and Indian Oceans. Systematic Botany 35(3): 461-475. doi: 10.160o/036364410792495935

Authors' contribution statement: RPF: Data collection, identification, and text writing. ACPS: Assistance in text structuring and writing. AFNP: Data collection and text writing. IAAS: Data collection and text writing. ICLB: Assistance in identification and full text review.

\section{Received: October 2014 \\ Accepted: March 2015}

Editorial responsibility: Mateus Paciência 